\title{
Gap between Expectations and Experiences of Equity in Public Schools: A Pupils' Perspective
}

\author{
Muhammad Uzair-ul-Hassan ${ }^{*}$
}

\begin{abstract}
The study investigated into the lens of pupils from public sector that what constitutes fair and equitable schools in Pakistan. Also the study explored pupils' expectations from school, how the schools can be transformed into equitable schools in which all students are treated equally and fairly. The study used quantitative approach with multistage sampling in two districts of Punjab, Pakistan. Questionnaire had been conducted on 434 pupils aged between 14-15 years of $9^{\text {th }}$ and $10^{\text {th }}$ class. The return rate of the questionnaire was $85 \%$. Results of descriptive statistical analysis show that pupils receive equitable as well as inequitable treatment with respect to punishment, rewards and marks awarded by teachers in public schools. Results further show that wider the inequitable experiences of pupils in schools, greater are the equity expectations from schools. Also the pupils with various backgrounds differ significantly from each other in terms of inequitable experiences in schools. It is concluded that equitable public school would be the one in which all students are treated in an equitable manner irrespective of differences.
\end{abstract}

Keywords: Pupils, equity, schools

\section{Introduction}

Pupils' voices based on their own experiences in schools have weight and worth in identifying inequitable schools. Inequitable schools reflect students' failure and social deprivation. The concept of equitable schools lies within the concept of equity. Equity, ensemble tackles school failure and helps to control the effects of deprivation in the society which sometimes causes school failure.

\footnotetext{
Department of Education, University of Sargodha.
} 
Skelton and Kigamwa (2013) explained that education would be equitable when educational practices, policies, curricula, resources and institutional cultures are representative of all students in terms of access and participation in high quality learning experiences regardless of their race, socio-economic status, gender, ability, religion, national origin, linguistic diversity or other characteristics. We have drawn a sketch map based on Skelton and Kigamwa's concept of equitable education below:

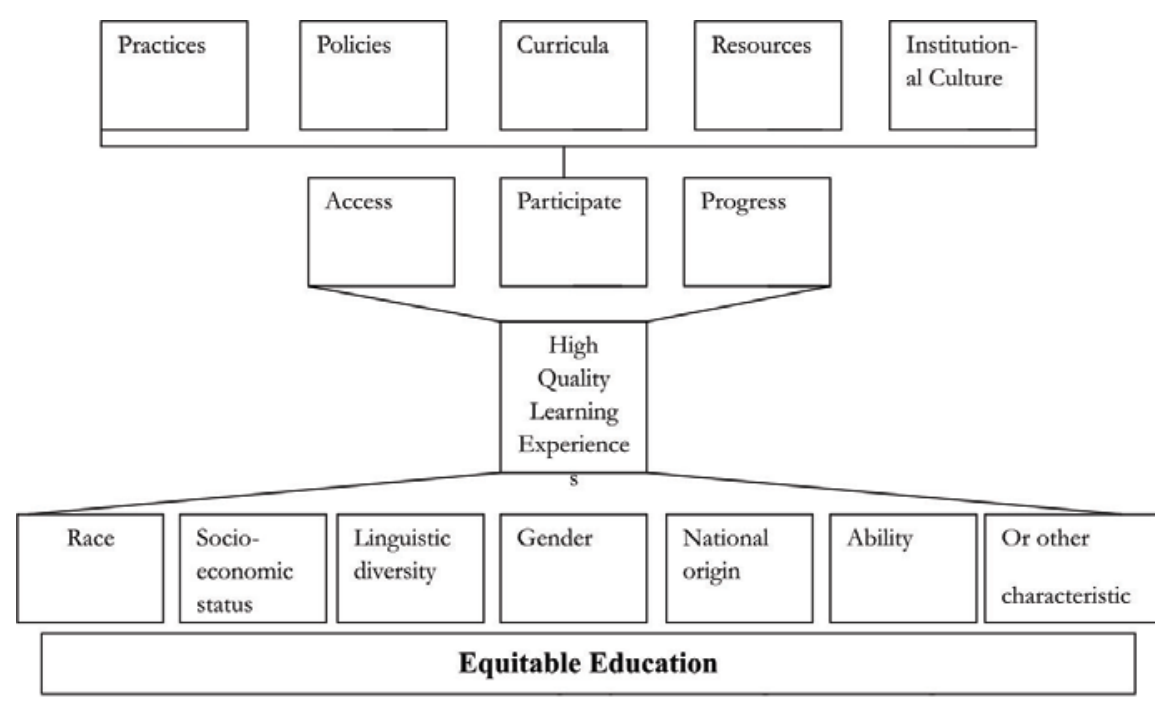

Figure 1. Equitable education

Equity has become increasingly prominent in national and international policy agendas (e.g. Ball and Youdell, 2009; UNESCO, 2007; OECD, 2005).Smith and Gorard (2006) explain that in a fair and equitable national education system all students must be treated in the similar fashion.

The study revolves around students' expectations from teachers in terms of fair and equitable treatment and how teachers have been treating students with regards to fairness and justice. If schools do not provide adequate fair and equitable experiences to pupils, then schools would keep on multiplying inequalities and be a burgeoning source of educational inequities. Our study gets benefit from English and French literature available on equity and operates under the umbrella of Hutmacher's (2002) theoretical approach towards equity and Merit's principles of educational equity that are embedded in Rawl's theory of 
justice. The study also gets guidelines from Smith and Gorard's (2006) work related to criteria of justice, judgments on the equity of the educational system and a feeling of being treated with justice. Schools must provide equitable experiences based on justice. It seems that whatever students reflect outside school is actually rooted in their experiences inside the school. What happens in school can impact on life outside and beyond school (Gorard 2011).Smith and Gorard's (2012) discussed the criteria of justice in terms of pupils' opinions about fair schooling system, judgments on the equity of the educational system in terms of students' expectation of equity, and a feeling of being treated with justice in terms of students' comportment about their equity experiences in their own school. Punishments, rewards, and marks awarded to pupils are also been discussed within equity in school. Teachers' expectations about students sway students' belief about themselves. The study investigates into how students perceive education system equitable in terms of teachers' treatment in schools. Students' expectation related to equity makes the criteria of equity and justice. What makes school system unfair and inequitable and to what extent students' experiences suggest students' own system is fair one? The study includes criteria of equity and justice, students' expectations and experiences of equity in schools. The study takes into account the inequitable experiences in terms of punishments, rewards, marks, and treatment of different groups of students in schools.

Boland and Potter (2001) elaborated that teacher's belief about students' potentials and abilities or disabilities affect students belief about themselves and consequently affect their efforts and achievements in schools. Equity (2000) concluded in its reform model that all students can learn to maximum when convenient working conditions with high expectations are provided. All schools should respect, greet and welcome all pupils, parents, and other members of the school community. Schools should have high expectation from all students. The schools should be equitable, fair and inclusive and must provide the kind of environment where all students and all members of the school community should feel accepted. McMurtry \& Curling, (2008) explained that new investments in education are not reaching to pupils who need because barriers to learning are not appropriately being addressed. The barriers concerning access, participation and outcomes entangle education and consequently these barriers exclude students from schools. According to Riley (2004), suggests that pupils perceive equality of treatment as highly unfair and show disruptive or rebellious behaviour. Smith and Gorard (2012) explained that there lie complications in deciding whether pupils are 
treated fairly or unfairly. Smith \& Gorard (2012) concluded that pupils' feelings of injustice are important for moral, academic, educational and civic reasons. They further elaborated that every pupil's development and achievement is equally important for the school system and unfairly treated pupils react that consequently can impair their learning process. In schools where much injustice exists, pupils can learn less. Smith and Gorard (2012) found that unfairness with pupils may harm the personal development and can lower self-esteem. Equity can be considered to represent sense of fairness. "Where equity is denied, negative consequences follow" (Smith \& Gorard, 2012). "If we view schools as micro-societies we might surmise that the learning of justice and fairness in school will help shape young people's notions of justice and equity outside school" (Smith \& Gorard, 2012). The study creates awareness among stakeholders i.e. students, parents and teachers that how students perceive unfairness, injustice and inequalities in schools. Students not only take into account inequalities that persist within their environment and among them but also feel and dislike disproportionate, prejudiced and discriminated dealing of teachers. The study contributes significantly in teachers' understanding on how students become sensitive during interactions and treatment of teachers in classroom and schools. Teachers can also get benefit from the study that what inequalities among students are justifiable and what are not. This study further assert the importance of equity in school because speaking at broader level the work force of the country would be made effective if every student within his or her capacity utilize maximum potential that $\mathrm{s} / \mathrm{he}$ possesses and can become a responsible citizen. Productive citizen can earn better. "The wages of a literate person are 23\% higher than those of an illiterate person in Pakistan” (Education for All, Global Monitoring Report, EFAGMR (2014: p. 146).

The objectives of the study were to;

1. Explore pupils' perceptions and experiences of equity in their school

2. Identify equity in teachers' behaviors' with students.

3. Examine pupil's expectations about fair schooling system

4. Find relationship between students' experienced equity and the equity they expect from schools

5. Examine significant differences in pupils' demographics in terms of students' expected and students' experienced equity in schools.

Based on the objectives, following research questions were formulated:

1. How do pupils face injustices from teachers in general? 
2. How do pupils face injustices from teachers in terms of punishments?

3. How do pupils face injustices from teachers in terms of marks and rewards?

4. Are teachers biased in their behaviors with students?

5. Do pupils face unfair experiences with peers in public schools?

6. What do pupils expect from schools in bringing equity in public school education?

7. Does relationship exist between students' experienced equity and the equity they expect from schools?

8. Do significant differences exist in pupils' demographics exist in terms of pupils' expected and experienced equity in public schools?

\section{Methodology}

Students of $9^{\text {th }}$ and $10^{\text {th }}$ class between the age 14-16 years in public schools of district Sargodha and Chiniot (Punjab, Pakistan) were selected as population of the study. Students comprise the population of the study as students are the key stakeholders that are directly affected by the unjust educational practices occurring in schools.

Multi-stage sampling had been used for the study. To select sample from the population, schools located in both urban and rural areas were randomly selected from the official list of schools available for these districts. In Pakistan, there exists segregated system of education in relation to gender so separate schools for both female and male were also randomly selected from the official list available for the districts. Researcher personally visited the selected schools and students of $9^{\text {th }}$ and $10^{\text {th }}$ grades were selected with kind cooperation and coordination of the heads of the institutions. We considered each class as a cluster for our study. These classes were selected on "class available basis" i.e. as per convenience. It means that in a single school, if only a single section of $9^{\text {th }}$ or $10^{\text {th }}$ had been available at the time of visit, that single class or the cluster either of $9^{\text {th }}$ or $10^{\text {th }}$ students at that point of time were selected for the study. In this way, the study used multi-stage sampling. While our sample would be as representative as practicable, it is not possible to say that every student aged 14 or 15 had an equal chance of being included in our study from both districts and that the sample would be truly random. Before administering the questionnaires from the students, researcher provided requisite instructions to the students which facilitated them in completing the questionnaires. Further, almost 514 questionnaires were 
distributed among the students and 434 were collected back. So the return rate of the questionnaire was $85 \%$. The sample of students who returned the questionnaires is given below:

Table 1

Sample of students from rural and urban schools

\begin{tabular}{lll}
\hline & Location of School & \\
& Rural & Urban \\
\hline Sample of Students & 173 & 261 \\
Total & 434 & \\
\hline
\end{tabular}

Table 2

Sample of students from girls and boys schools

\begin{tabular}{lll}
\hline & Gender & \\
& Girls & Boys \\
\hline Sample of Students & 139 & 295 \\
Total & 434 & \\
\hline
\end{tabular}

\section{Instrument}

Researchers requested and received questionnaire on equity in school from Smith and Gorard who designed the questionnaire to collect data from schools in United Kingdom. Researchers further adapted the questionnaire and formulated three sets of indicators taken from Smith and Gorard (2006). The indicators were criteria of justice or equity i.e., expected equity, judgments on the equity and experienced equity in school. Smith and Gorard' (2006) indicators are underpinned in Meuret's (2002) work who had derived indicators for educational equity considering principally Rawl's theory of justice. The questionnaire comprised of a series of closed questions which were rated on a fivepoint scale i.e. Likert scale (from strongly agree to strongly disagree, with an opportunity for a neutral response). We used questionnaire as the instrument for our study that consisted of four sections, each of which addressed a particular domain of equity based on justice. The first part of the questionnaire related to students' experiences of equity in schools. The statements under this portion related to equitable or inequitable experiences of students in their own schools in terms of punishments and rewards, marks, and treatment of different groups of students in schools. The second section was concerned with pupils' perceptions about criteria 
of equity. This portion meant to find out the expectations of students from school on equity. These two parts of the questionnaire also facilitated in seeking relationship between students experienced and expected equity. On the other hand the demographic variables included in the questionnaire particularly mother tongue, father income, school locality and type of school further developed understanding on students' expected and experienced equity in public schools. The questionnaire was adapted and translated in Urdu and expert opinion was taken for validation of content, construct and the translation. The questionnaire was piloted with 34 students who had similar characteristics with main sample of the study. Pilot testing of the instrument was conducted and internal consistency of the items was calculated. To enhance the internal consistency, two item were deleted from the main questionnaire. Finally the value of the Cronbach Alpha was found 0.795 which indicated that there was a good consistency in responses against the items and that the data received on the instrument was reliable. Once the questionnaire had been finalized after pilot testing, data were collected from different schools across Sargodha and Chiniot districts from Punjab, Pakistan.

\section{Data Analysis}

Depending upon the characteristics, quality and nature of the data, a suitable statistical model was used to decompose the collected data. The data were collected on four sections in which various questions on aspects of educational equity were asked from the students. The first section dealt with students' equity criteria, second portion related to students' sense of justice, aspiration, and expectations, and the third section was related to students' experience of injustice in school. The second section discussed the equity criteria as students perceive. The third section related to the statements concerning what students have experienced in schools. These both sections i.e. section two and three were analyzed in parallel so that gap between "what should be" and "what is" could be discussed. This also facilitated in reflecting the comparison between actual and desired treatment in school. The statements given under the criteria for equity and students' sense of justice were related with praise for students and extra help given by teachers, fairness of teachers in a school (students' sentiments on justice), how teachers treat hardworking students, whether teachers give equal respect to all, does teacher humiliate pupils in class?, sentiments of students on marks awarded to them according to the efforts they made, equitable teaching, teachers' punishment and favoritism in class. By using a statistical tool 
“statistical programme/package for social sciences” IBM SPSS 19 (version), data were decomposed and analyzed to find the results for research questions. The results were tabulated and interpreted.

\section{Results}

Results are being explored through percentage analyses that provide us understanding of students' unfair and inequitable experiences, practices, behaviors and fair and equitable expectation from public schools. As far as criteria of equity are concerned, $41 \%$ students reply in favor of same respect to all, irrespective of differences. While $88 \%$ respondents think, that it is unfair for the students who work hard but are awarded with less marks. Also there were $67 \%$ of students who believed that students' personal effort more meaningful in coming out of the difficulties in reading and to keep on moving along with fellows while $48 \%$ of students were justified to impart more time to student who badly behaves in the class. The tables below shows percentage of respondents against each item related to equity experienced and expected.

Table 3

Percentage of responses against each item related to equitable experiences

\begin{tabular}{lll}
\hline Sr. No. & Experienced Equity & Percentage \\
\hline 1 & Pupil receive marks as they deserved & 85 \\
2 & Teachers even disagreed respected my opinions & 65 \\
3 & Teacher spends more time with a pupil with difficulties than others & 55 \\
4 & Teachers provide more help to those who needed & 90 \\
5 & Pupils were always treated fairly by teachers & 94 \\
6 & Teachers treated all pupils equal & 88 \\
7 & Pupils think their teachers are fair & 94 \\
8 & Pupils' marks reflect assignment quality & 87 \\
9 & Teachers punish some pupils more than others & 58 \\
10 & Teachers punish bad behavior fairly & 74 \\
11 & I felt as an invisible to teachers & 29 \\
12 & Teachers had favorite pupils & 59 \\
\hline
\end{tabular}

The table related to percentage analysis of each statement included in the questionnaire shows that eighty six percent $86 \%$ students positively responded that pupils got the marks that they deserved. Sixty percent and $65 \%$ of the students agreed to the statements i.e. 'teachers respected my opinions even when they disagreed' and 'teachers respected pupil's opinions even if they disagreed' respectively. Fifty five percent 55\% 
students think that teacher spends more time helping a pupil with difficulties than other pupils. Ninety percent $90 \%$ students responded that teachers gave extra help to those pupils who needed it. Ninety four percent 94\% students experienced that they were always treated fairly by their teachers. Similar majority of teachers i.e. 88\% experienced that teachers treated them no better or worse than other pupils. Ninety five percent 95\%students also experienced that they trusted their teachers to be fair and $94 \%$ think that their schools were a fair place. Eighty seven percent $87 \%$ respondents agreed that students' marks usually reflected the quality of work. Fifty eight percent 58\% students agreed that some pupils were punished more than others for the same offence. Seventy four percent $74 \%$ students also perceived that teachers punished bad behavior fairly. Twenty nine percent 29\% students responded that they are invisible to teachers in the class on the statement, 'I felt as though I was invisible to most teachers'. Fifty nine percent 59\% students perceived that teachers had favorite pupils.

Table 4

Percentage of responses against each item related to students' expected equity

\begin{tabular}{lll}
\hline Sr. No. & Expected equity & Percentage \\
\hline 1 & Teachers should give more time in improving students with & 28 \\
& difficulties & 87 \\
2 & Teachers should praise pupils who deserve it. & 74 \\
3 & Teachers must not humiliate pupils & 87 \\
4 & Pupils' marks should show assignment quality & 89 \\
5 & Teachers should explain until all pupils understand & 74 \\
6 & Teachers must not humiliate pupils & \\
\hline
\end{tabular}

The table related to percentage analysis of each statement included in the questionnaire shows that twenty eight percent 28\% students positively signal that teachers should give more time in improving students with difficulties. Eighty seven percent $87 \%$ students expect that teachers should praise pupils who deserve it. Seventy four percent $74 \%$ students agree that teachers should take care not to humiliate pupils. Eighty seven percent $87 \%$ students agreed that pupils' marks should reflect the quality of their work. Eighty nine percent $89 \%$ students agreed upon 'teachers should continue explaining until all pupils understand the topic'. Seventy four percent $74 \%$ students agreed that teachers should take care not to humiliate pupils. Eighty seven percent $87 \%$ students agreed that pupils' marks should reflect the quality of their work. 
The table below reflects relationship exist between students' experienced equity and the equity they expect from schools:

Table 5

Pearson product Moment Correlation showing relationship between students' expected equity and students' experienced equity in schools

\begin{tabular}{lll}
\hline Students Expected Equity & Students Experienced Equity & $\mathrm{r}^{2}$ \\
\hline $.420^{\star *}$ & $.420^{\star *}$ & .000 \\
\hline
\end{tabular}

Where $n=426$

${ }^{* *} p<0.01$

Pearson product Moment Correlation shows that there is positive relationship between students' expected equity and students' experiencing equity $(r=0.420)$. Scatter plot to this correlation is shown below:

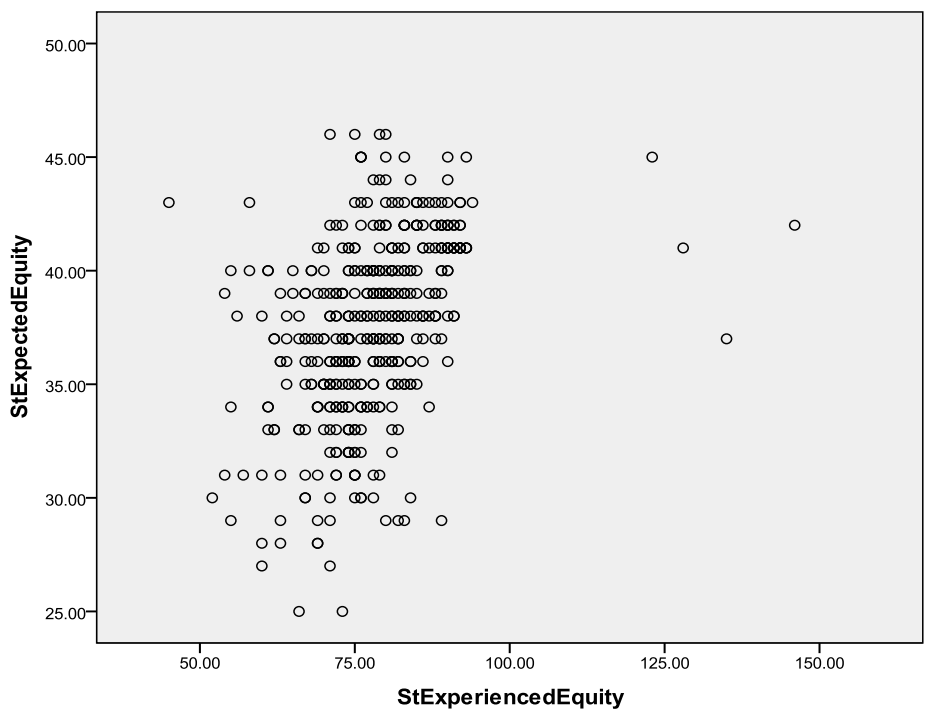

Figure 1. Scatter plot

The scatter plot shows that there exists a positive relationship between students' expected equity and students' experienced equity in schools $(r=0.420)$.

This portion of the analyses provide us frequency response of the students on the basis of various demographic variables e.g., mother 
tongue and father's income. It also shows us the significance differences in the mean score of students' experienced and expected equity with respect to various demographic variables e.g., mother tongue, locality and type of schools and students' father income.

The tables below show some of the demographic variables related to students' mother tongue and father's income included in the study.

Table 6

Students' mother tongue

\begin{tabular}{llll}
\hline Sr. No. & $\begin{array}{l}\text { Students' mother } \\
\text { tongue }\end{array}$ & Response Frequency & Response in Percentage \\
\hline 1 & Urdu & 226 & 52.1 \\
2 & Punjabi & 205 & 47.2 \\
3 & Pashto & 3 & 0.7 \\
\hline Total & & 434 & \\
\hline
\end{tabular}

The table shows that $52 \%$ students' mother tongue is Urdu while $47 \%$ students speak Punjab as a mother language.

Table 7

Students' father income

\begin{tabular}{llll}
\hline Sr. No. & $\begin{array}{l}\text { Students' father } \\
\text { income in Pak Rs }\end{array}$ & Response Frequency & Response in Percentage \\
\hline 1 & Below 15000 & 231 & 54.9 \\
2 & $15000-25000$ & 55 & 13.1 \\
3 & $26000-35000$ & 21 & 5.0 \\
4 & $36000-45000$ & 19 & 4.5 \\
5 & $46000-55000$ & 6 & 1.4 \\
6 & $56000-65000$ & 2 & 0.5 \\
7 & More than 650000 & 4 & 1.0 \\
8 & Do not know & 81 & 19.2 \\
9 & Father late & 2 & 0.5 \\
Total & & 434 & \\
\hline
\end{tabular}

The table shows that father's income of 55\% students is below PK Rs15000 per month and fathers of $13 \%$ of students earn between PK Rs 15000 to 25000 monthly. This information helps further for the detailed analysis to understand equity in education. 
Table 8

Independent sample t- test comparing expected schools' equity based on students' mother tongue

\begin{tabular}{llllllll}
\hline $\begin{array}{l}\text { Sr. } \\
\text { No. }\end{array}$ & $\begin{array}{l}\text { Dependent } \\
\text { variable }\end{array}$ & $\begin{array}{l}\text { Mother } \\
\text { tongue }\end{array}$ & N & Mean & $\begin{array}{l}\text { Std. } \\
\text { Deviation }\end{array}$ & t & $\begin{array}{l}\text { Sig. (2- } \\
\text { tailed) }\end{array}$ \\
\hline 1 & $\begin{array}{l}\text { Students' } \\
\text { expected equity }\end{array}$ & Punjabi & 202 & 38.7598 & 3.24017 & 6.036 & .000 \\
& & Urdu & 225 & 36.5156 & 4.32197 & & \\
\hline
\end{tabular}

The independent sample t-test Table shows that there is significant difference between students whose mother tongue is Punjabi and whose mother tongue is Urdu and who expect schools' equity. $(\mathrm{t}=6.036$, Sig. $=$ .000 , Mean Punjabi $=38.7598$, Mean Urdu $=36.5156$.

Table 9

Independent sample t- test comparing students who are experiencing schools' equity based on students' mother tongue

\begin{tabular}{llllllll}
\hline $\begin{array}{l}\text { Sr. } \\
\text { No. }\end{array}$ & $\begin{array}{l}\text { Dependent } \\
\text { variable }\end{array}$ & $\begin{array}{l}\text { Mother } \\
\text { tongue }\end{array}$ & $\mathrm{N}$ & Mean & $\begin{array}{l}\text { Std. } \\
\text { Deviation }\end{array}$ & t & $\begin{array}{l}\text { Sig. (2- } \\
\text { tailed) }\end{array}$ \\
\hline 1 & $\begin{array}{l}\text { Students' } \\
\text { experiencing } \\
\text { equity }\end{array}$ & Punjabi & 199 & 80.3719 & 10.99414 & 5.198 & .000 \\
2 & & Urdu & 225 & 75.3839 & 8.71188 & & \\
\hline
\end{tabular}

The independent sample t-test Table shows that there is significant difference between students whose mother tongue is Punjabi and whose mother tongue is Urdu and who are experiencing equity at schools $(\mathrm{t}=$ 5.198, Sig. $=.000$, Mean Punjabi $=80.3719$, Mean Urdu $=75.3839$.

Table 10

Independent sample t- test comparing rural and urban students who expect equity from schools

\begin{tabular}{llllllll}
\hline $\begin{array}{l}\text { Sr. } \\
\text { No. }\end{array}$ & $\begin{array}{l}\text { Dependent } \\
\text { variable }\end{array}$ & Locality & $\mathrm{N}$ & Mean & $\begin{array}{l}\text { Std. } \\
\text { Deviation }\end{array}$ & $\mathrm{t}$ & $\begin{array}{l}\text { Sig. (2- } \\
\text { tailed) }\end{array}$ \\
\hline 1 & $\begin{array}{l}\text { Students' } \\
\text { expected equity }\end{array}$ & Urban & 260 & 36.7154 & 4.09886 & -5.774 & .000 \\
2 & & Rural & 172 & 38.9012 & 3.44321 & & \\
\hline
\end{tabular}

The independent sample t-test Table shows that there is significant difference between urban and rural schools students who expect equity 
from their schools $(\mathrm{t}=-5.774$, Sig. $=.000$, Mean Urban $=36.7154$, Mean Rural $=38.9012$.

Table 11

Independent sample t- test comparing rural and urban students who are experiencing schools' equity

\begin{tabular}{llllllll}
\hline $\begin{array}{l}\text { Sr. } \\
\text { No. }\end{array}$ & $\begin{array}{l}\text { Dependent } \\
\text { variable }\end{array}$ & Locality & N & Mean & $\begin{array}{l}\text { Std. } \\
\text { Deviation }\end{array}$ & t & $\begin{array}{l}\text { Sig. (2- } \\
\text { tailed) }\end{array}$ \\
\hline 1 & $\begin{array}{l}\text { Students' } \\
\text { expected equity }\end{array}$ & Urban & 259 & 74.5405 & 8.65495 & -8.894 & .000 \\
& & Rural & 167 & 82.7725 & 10.28197 & & \\
\hline
\end{tabular}

The independent sample t-test Table shows that there is significant difference between urban and rural schools students who are experiencing equity in schools $\mathrm{t}=-8.894$, Sig. $=.000$, Mean Urban $=$ 74.5405, Mean Rural $=82.7725$.

The independent sample t-test shows that there is no significant difference between male and female students who expect schools' equity. $\mathrm{t}=-1.871$, Sig. $=.062$, Mean Male $=37.3401$, Mean Female $=38.1087$. The independent sample t-test shows that there is no significant difference between male and female students who experienced schools' equity (annex.). $\mathrm{t}=1.167$, Sig. $=.244$, Mean Male $=78.1581$, Mean Female $=76.9259$.

Table 12

ANOVA comparison of students expected equity from schools and their fathers' income

\begin{tabular}{llllll}
\hline Sr. No. & Dependent variable & Variance & $\mathrm{df}$ & $\mathrm{F}$ & Sig. \\
\hline 1 & Students expected equity & Between & 8 & 2.353 & .018 \\
& & groups & & & \\
& & Within groups & 411 & & \\
& & Total & 419 & & \\
\hline
\end{tabular}

Table 12 shows that there is significant difference in students' expected equity from schools and their fathers' income $(\mathrm{F}=2.353$, Sig. $=.018)$.

Post hoc multiple comparisons show that significant difference is found in students who did not provide information about their fathers' income and whose fathers are late. But no significant difference is found in students' expectation of schools' equity on the basis of other categories of fathers' income. One-way ANOVA was also used to compare students experienced equity in schools and their fathers' 
income. The result shows that there is no significant difference in students' experienced equity in schools and their fathers' income ( $\mathrm{F}=$ .566 , Sig. $=.806$ ).

This portion provides the overall reflection about teachers' treatment with students. A well proportion of students experienced that their schools are a fair place and their teachers are able, good and hardworking but in parallel they also pointed out grids where teachers are inequitable and so the public schooling system as well. It appears from overall reflection that although gaps exist between students' desired or expected equity to public schooling and to those students who are actually experiencing equity or inequity in the system. The gaps exist although little and for that the possible explanation might be Pakistani culture where submissiveness and compliance for teachers prevails. It is worthnoting that Pearson Product Moment Correlation shows positive relationship between students' judgment on equity and perception of being treated with justice. Rural schools students expect more equity in schools as compared to urban schools students in Pakistan. As for as experiencing equity is concerned rural schools students are better experiencing as compared to urban schools students. Punjabi speaking students expect more equity from schools as compared to Urdu speaking students. On the other hand, Punjabi speaking students are experiencing more equity as compared to Urdu speaking students which seems contradictory.

\section{Discussion}

The demographic variables might have influence students' sense of justice, aspiration and expectation of equity. For example, rurality, mother tongue, father' income, education, and profession showed significant differences on students' expected and experienced equity in schools. It is also worth-noting that a suffice proportion of students didn't share their father's income. The reason may probably be either they wanted to hide the information or they do not know the income of their fathers. Teachers considered it fair to spend more time helping a pupil with difficulties. On the other hand, teachers considered it unfair if time is distributed equally among all students. Smith and Gorard (2006) found that pupils express concern for less able peers in primary schools. Moreover, they elaborated that pupils in UK, felt that teachers should give equal attention to all pupils. For a well proportion of the students, it is equitable that students' personal effort is more meaningful and these are justifiable to come out of the difficulties in reading and to keep on 
moving along with counterparts in the class. A little gap was found between how students like their teachers to treat hardworking students and how actually teachers are treating hardworking students. One possible reason may be of cultural submissiveness and compliance of pupils to teachers as students generally consider teachers as authority and do not feel free to speak against even when teachers are wrong. According to Smith and Gorard (2006), most pupils in UK want that all pupils should be treated the same while in France, Spain, Belgium and Italy, more pupils want greater attention for the least able. Our study also shows that some pupils were punished more than others for the same offence. Due to this reason, students perceive injustice with some students in the class. On the other hand, the students also perceive that teachers punished bad behavior fairly. Although, students frequently expressed students-teachers relationship in schools positively but they have equally pinpointed that teachers also use punishment as a tool either for study or for management in classes. Although, students frequently and positively expressed students-teachers relationship in schools but they have in parallel considered punishment as unfair on the part of teachers. Invisible students are actually experiencing injustice within the environment of favoritism in the class. A sufficient proportion of students perceived that they are invisible. It appears from overall reflection that although gaps exist between students' desired or expected equity in schools and to within those students who are actually experiencing equity or inequity in schools. The gaps exist although little and for that the possible explanation might be Pakistani culture where submissiveness and compliance for teachers prevails. This is similar what Smith and Gorard (2012) pointed out students' reluctance to express opposition to authority. Probably, students are less aware of the situations to decide what is equitable and fair and what is not. This is also what Smith and Gorard (2012) explained that the issues related to equity were less familiar to the group of students. Pupils have not considered fair that there should be equal relationship between teacher and pupils. Smith and Gorard (2012) concluded that students share roughly similar types of experiences, both positive and negative despite the obvious cultural, social and structural differences between schools. It is worth-noting that positive relationship exists between students' judgment on equity and perception of being treated with justice. The study indicates that rural schools students expect more equity in schools as compared to urban. Similarly, rural school students are experiencing more equity in schools as compared to urban. On languages, Punjabi speaking students expect more equity in schools as compared to Urdu 
speaking. On the other hand, Punjabi speaking students are experiencing more equity as compared to Urdu speaking that is quite contradictory. Father's income became vital component in students' expectation on equity in schools. Poor students expect more equity in schools. Similarly students who did not provide information of father's income also expect more equity in schools. In a nutshell, the study introduces equity in schools as significant research field and justifies that screening of just few children as compared to the rest is harmful for the country's educational set up in all aspects where schools themselves become barrier to produce more productive citizens for the country and society. Equitable public school would be the one in which all students are treated in an equitable manner irrespective of differences.

\section{Acknowledgement}

I am grateful to Professor Stephen Gorard and Professor Emma Smith who has given approval to get benefit from questionnaire on equity. 


\section{References}

Ball, S. J. and You dell, D. (2009). Hidden privatisation of public education. Education Review. 21(2), 73-83.

Boland, P. \& Potter, J. (2001). Gender equity for educators, parents and community. Equity in education series. WEEA Equity Resource Center. Education Development Center, Inc. Retrieved from www2.edc.org/gdi. EFAGMR. (2014). Education for All Global Monitoring Report 2013/14. Paris: UNESCO.

Equity (2000). Equity 2000-A systematic education reform model: A summary report 1990-2000. Retrieved from www.collegeboard.com. Gorard, S. (2011). The potential determinants of young people's sense of justice: An International study. British Journal of Sociology of Education. 32(1), 35-52.

Gorard, S., and Smith, E.(2010). Equity in education: An international perspective London: Palgrave MacMillan. Govt. of Pakistan.(1998). National Education Policy (1998-2010). Ministry of Education, Islamabad. Pp. 47, 72.

Hutmacher, W. (2002). Introduction in, In pursuit of equity in education: Using International Indicators to Compare Equity Policies. Kluwer Academic Publishers: New York.

McMurtry, R. \& Curling, A. (2008). The review of the roots of youth violence. Vol. 2: Executive Summary. Toronto: Queen's Printer for Ontario.

Meuret, D. (2001) School Equity as a Matter of Justice, in In Pursuit of Equity in Education, Hutmacher, W., Cochrane D., Bottani N. (eds.), Dordrecht: Kluwer Academic Publishers.

Meuret, D. (2002).School Equity as a Matter of Justice. In pursuit of equity in education: Using International Indicators to Compare Equity Policies. Hutmacher, W., Cochrane D., Bottani N. (eds.).New York: Kluwer Academic Publishers. 
Meuret, D. (2002). A System of Equity Indicators for Educational Systems. In Inpursuit of equity in education: Using International Indicators to Compare Equity Policies. Hutmacher, W., Cochrane D., Bottani N. (eds.), Kluwer Academic Publishers: New York.

Organization for Economic Co-operation and Development, OECD. (2005). Teachers Matter: Attracting, developing and retaining effective teacher. Paris, France: Organisation for Economic Cooperation and Development Publishing.

Organization for Economic Co-operation and Development, OECD (2008). Ten steps to equity in education. Policy brief, Organization for Economic Cooperation and Development, OECD.

Retrieved from www.oecd.org/edu/equity/equityineducation.

Riley, K. (2004). Voices of disaffected pupils: Implications for policy and practice. British Journal of Educational Studies.52 (2),166-79.

Skelton, S. \& Kigamwa, J. (2013). Educational equity: What's it all about? Great lakes equity centre. Retrieved from http://glec.education.iupui.edu/assets/files/JulyPDF.pdf

Smith, E., \& Gorard, S. (2006). Pupils' view on equity in schools. Compare, 36(1),41-56.

Smith, E., \& Gorard, S. (2012) 'Teachers are kind to thosewho have good marks': a study of Japanese young people's views of fairness and equity in school, Compare: A Journal of Comparative and International Education. 42(1), 27-46. DOI:10.1080/03057925.2011.629073.

UNESCO. (2007). Educational equity and public policy: Comparing results from 16 countries. Montreal: UNESCO.

Received on: February 22, 2016

Revised on: May 21, 2016

Accepted on: June 05, 2016 